\title{
SCIENTIFIC AND TECHNICAL DEVELOPMENT \\ OF SPACE INDUSTRY ENTERPRISES: \\ NATIONAL AND INTERNATIONAL ASPECT
}

\section{Olga Dzhur ${ }^{1}$ \\ Yevhen Dzhur ${ }^{2}$}

DOI: https://doi.org/10.30525/978-9934-26-021-6-16

Abstract. The purpose of the article is to study and highlight promising areas of development of the space industry of Ukraine based on the potential of scientific and technical development, which was formed in at least years of space industry of Ukraine taking into account political, economic, social trends in Ukraine and the international economy. The methodological and informational basis of the study are the works of national and international statistical publications and reports, publications of consulting companies, information materials of space companies. To achieve this goal, a systems approach, correlation-regression analysis, methods of historical and logical approach, dialectical development, linguistic level of description of systems as the highest level of abstraction were used. Assessment of the success of modern world business and prospects of scientific and technological development of high-tech business, in particular space enterprises was analyzed using reports of such well-known publications as Fortune, McKinsey, SRG, MIT Technology, statistics of international organizations OECD, WIPO, World Bank, statistics State Statistics Service of Ukraine, State Space Agency of Ukraine. Value / originality. Comparative analysis of scientific and technical development of successful international economies, world aerospace business and scientific and technical development of Ukraine's economy and its space industry revealed weaknesses in the further development of space enterprises, propose measures to eliminate shortcomings, propose a scheme for selecting promising scientific and

\footnotetext{
${ }^{1} \mathrm{PhD}$ in Technical Sciences,

Associate professor of Department of Marketing and International Management,

Oles Honchar Dnipro National University, Ukraine

${ }^{2}$ Professor, Dr. in Technical Sciences,

Professor of Department of Production Technology,

Oles Honchar Dnipro National University, Ukraine
} 
technical directions. industry and explore some correlation of important components of innovation development to the Global Competitiveness Index (GCI).

\section{Introduction}

Modern economic realities are characterized by a high level of environmental uncertainty, high competition, limited and high cost of resources, internationalization of activities and determine the search for managers and specialists in the field of effective management tools that would allow it to operate stably and constantly develop, improve its competitors in the international market. The scientific and technical sphere is in the focus of attention of both individual countries with different levels of economy and large international organizations. Scientific and technical developments that have been implemented have significantly improved the welfare of those economies that have been able to effectively ensure their process of emergence, implementation and implementation in the real sector of the economy. Identifying promising scientific and technical areas of development that will ensure key success factors for space enterprises in Ukraine is a strategic task for both the enterprises themselves and the Government of Ukraine. This issue is becoming relevant in connection with the proposal for further transformation of enterprises in the space industry of Ukraine, the introduction of corporate reform of the State Space Agency of Ukraine. The current study aims to identify and analyze the qualitative and quantitative characteristics of the scientific and technical development of space enterprises in the context of global trends in modern economies.

\section{Global trends in science and technology}

The industrial revolutions led to the emergence of a large number of innovations, which were implemented by advanced economies, contributed to the growth of GDP and improved the lives of the population. Today, the world is experiencing 4 industrial revolutions, which are associated with significant digitalization of society, further ambitious development of hightech and science-intensive organizations, the introduction of high technology in traditional industries, further internationalization of economic relations. These interpenetrating processes contribute to the modernization of business forms, intensification of the development of international projects in the 
scientific and technical sphere, improvement of forms of management at the state level and individual operating (production) systems.

Every year, large international organizations, consulting firms, various research centers, well-known business representatives and individual scientists offer their forecasts for the development of world economies.

For example, in 2019, the consulting company McKinsey presented a report on technologies that can change lives, businesses and the global economy in the coming years. Analysts predict that by 2025 the potential economic effect of the introduction of such technologies will be in the range of \$ 14-33 trillion. This analysis is based on an in-depth analysis of key potential benefits, including better quality products and lower prices. The report includes the following technological areas: mobile Internet; automation; internet of things; cloud computing; advanced robotics; autonomous vehicles; next-generation genomics; new means of energy storage; 3D printing; improved materials and fuel; renewable energy sources [1].

The authoritative American publication Fortune compiles annual rankings of successful companies. The performance of the 20 most successful companies are presented in table 1 [2].

The data in Table 1 show the ambiguity of the processes that companies underwent in 2019 due to the impact of covid-19. Despite the income of American business giants, the profitability of some of them was insignificant or even negative compared to the previous period. In the list of the top twenty companies stand out Health Care companies, which is certainly due to the specifics of the crisis covid-19. Successful aerospace companies start at 39th in the rankings, indicating the complexity of managing such complex high-tech systems. In its report on science, technology and innovation, the Organization for Economic Co-operation and Development (OECD) notes that «the world is facing unprecedented changes marked by uncertainties and unknowns» because of Covid-19. «The fast pace of technological change, including developments in artificial intelligence and synthetic biology, adds to these uncertainties and makes policy oversight of emerging technologies increasingly difficult» [3]. Undoubtedly, the global nature of such events suggests that the solution will require international cooperation.

SRG Group of Companies, one of the leading consulting groups, singled out among the scientific trends of 2020: 1) responding to pandemics; 2) powering 


\section{0 most successful US companies}

\begin{tabular}{|c|c|c|c|c|c|}
\hline 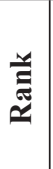 & Name of company (Industry) & 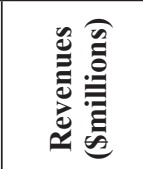 & 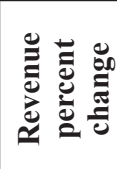 & 递 & 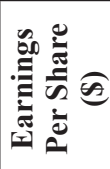 \\
\hline 1 & Walmart (General Merchandise) & 523,964 & $1,9 \%$ & 2200000 & 5.19 \\
\hline 2 & $\begin{array}{l}\text { Amazon (Internet and Direct } \\
\text { Marketing Retail) }\end{array}$ & $\$ 280,522$ & $20,5 \%$ & 798000 & 23.01 \\
\hline 3 & ExxonMobil (Petroleum Refining) & $\$ \$ 264,938$ & $-8,7 \%$ & 74900 & 3.36 \\
\hline 4 & Apple (Computers, Office Equipment) & $\$ 260,174$ & $-2 \%$ & 137000 & 11.89 \\
\hline 5 & $\begin{array}{l}\text { CVS Health (Health Care: Pharmacy } \\
\text { and Other Services) }\end{array}$ & $\$ 256,776$ & $32 \%$ & 290000 & 5.08 \\
\hline 6 & $\begin{array}{l}\text { Berkshire Hathaway (Insurance: } \\
\text { Property and Casualty (Stock)) }\end{array}$ & $\$ 254,616$ & $2,7 \%$ & 391500 & 49.828 \\
\hline 7 & $\begin{array}{l}\text { UnitedHealth Group (Health Care: } \\
\text { Insurance and Managed Care) }\end{array}$ & $\$ 242,155$ & $7 \%$ & 325000 & 14.33 \\
\hline 8 & McKesson (Wholesalers: Health Care) & $\$ 214,319$ & $2,9 \%$ & 70000 & 0.17 \\
\hline 9 & AT\&T (Telecommunications) & $\$ 181,193$ & $6,1 \%$ & 247800 & 1.89 \\
\hline 10 & $\begin{array}{l}\text { AmerisourceBergen (Wholesalers: } \\
\text { Health Care) }\end{array}$ & $\$ 179,589$ & $6,9 \%$ & 21500 & 4.04 \\
\hline 11 & $\begin{array}{l}\text { Alphabet (Internet Services and } \\
\text { Retailing) }\end{array}$ & 161857 & $18,3 \%$ & 798905,3 & 49.16 \\
\hline 12 & Ford Motor (Motor Vehicles \& Parts) & 155900 & $-2,8 \%$ & 19150,6 & 0.01 \\
\hline 13 & $\begin{array}{l}\text { Cigna (Health Care: Pharmacy and } \\
\text { Other Services) }\end{array}$ & 153566 & $215,7 \%$ & 65896,7 & 13.44 \\
\hline 14 & $\begin{array}{l}\text { Costco Wholesale (General } \\
\text { Merchandisers) }\end{array}$ & 152703 & $7,9 \%$ & 125907,7 & 8.26 \\
\hline 15 & Chevron (Petroleum Refining) & 146516 & $-11,9 \%$ & 136175,9 & 1.54 \\
\hline 16 & $\begin{array}{l}\text { Cardinal Health (Wholesalers: Health } \\
\text { Care) }\end{array}$ & 145534 & $6,4 \%$ & 13988,1 & 4.53 \\
\hline 17 & $\begin{array}{l}\text { JPMorgan Chase (Banks: Commercial } \\
\text { and Savings) }\end{array}$ & 142422 & $8,4 \%$ & 276750,1 & 10.72 \\
\hline 18 & $\begin{array}{l}\text { General Motors( Motor Vehicles \& } \\
\text { Parts) }\end{array}$ & 137237 & $-6,7 \%$ & 29694,7 & 4.57 \\
\hline 19 & $\begin{array}{l}\text { Walgreens Boots Alliance (Food \& } \\
\text { Drug Stores) }\end{array}$ & 136866 & $4,1 \%$ & 40528,2 & 4.31 \\
\hline 20 & $\begin{array}{l}\text { Verizon Communications } \\
\text { (Telecommunications) }\end{array}$ & 131868 & $24,1 \%$ & 222220 & 4.65 \\
\hline
\end{tabular}


the eco revolution; 3) edge computing; 4) natural language processing (NLP); 5) 2020: a Space Odyssey; 6) greater diversity in STEM [4].

In his study of trends in global science and technology J. A. Armstrong highlights the following trends [5]:

1) more surprises from science (the ability of companies and countries to support research is key to economic development and success; the ability to quickly transform scientific results into end products is an even more important factor for companies and countries; rapid change of leaders and the disappearance of entire industries is possible);

2) proliferation and globalization of research («continuing expansion in the topics of research and an increasing globalization of the way research is conducted by private firms»);

3) short, quick steps at a premium («many industries place great emphasis on incremental refinements in technology and that in most cases there is great pressure to collapse the elapsed time from a discovery in science to resulting product application»).

Microsoft founder Bill Gates in 2019 at the request of MIT Technology Review identified the following list of technologies that will change the world in the near future: 1) nuclear energy of the new generation; 2) agile and skillful work; 3) personalized cancer vaccines; 4) forecasting premature births; 5) tablet instead of a gastric tube; 6) advanced voice assistants; 7) toilets without sewage and harmful bacteria; 8) meat from a test tube; 9) carbon dioxide absorber;10) ECG on the wrist. This list shows that successful business owners and researchers pay special attention to technologies that increase the quality of life, make people happier, help people live a fulfilling life and create meaningful connections within society [6].

The intensity of R\&D in any country is clearly reflected in the number of patents, utility models, trademarks and industrial designs. The World Intellectual Property Organization (WIPO) in its 2019 report showed that applications worldwide of patents, trademarks and industrial designs, are growing fast. From 2008 to 2018, the following growth of intellectual property took place: 1) the number of patents increased from 1930000 to $3326300(72.3 \%), 2)$ the number of trademarks increased from 5511200 to $14321800(159.9 \%), 3)$ the number of industrial designs increased from 814,800 to $13,12600(61.1 \%)$. In one year, from 2017 to 2018 , the world economy showed the following growth of intellectual property: 
1) patents $-5.2 \%$; 2) utility models $-21.8 \%$; 3) trademarks $-15.5 \%$; 4) industrial designs $-5.7 \%$. China's office received a record total of 1,54 million patent applications in 2018, followed by the U.S., Japan, the Republic Korea and the EPO. China recorded a double-digit growth in 2018, while patent filings slightly dropped in the U.S. and Japan. From 2018 to 2019 , the situation was somewhat unstable. The world economy demonstrates the following growth rates of intellectual property: 1) patents $-(-3.0 \%)$; 2) utility models $-9.1 \%$; 3) trademarks $-5.9 \%$; 4) industrial designs $1.3 \%$; 5) plant varieties $-7.8 \%$. In China, the following growth rates of IPR were observed: for patents $-(-9.2 \%)$; for utility models $-6.4 \%$; on trademarks -6.4 ; for industrial designs $-0.4 \%$; of plant varieties $-36 \%$. In the United States, the following growth rates of intellectual property (IPR) were observed: for patents $-4.1 \%$; on trademarks $-5.1 \%$; of plant varieties $(-1.2 \%)$. WIPO data show a slowdown in IPR processes in all countries of the world.Крім того, у статистиці цієї організації видно, що Online sales generated more than half of trade sector revenue in Sweden and the U.K. «The U.S., with USD 16.2 billion, reported the largest revenue, followed by Japan (USD 8.9 billion), the Republic of Korea (USD 3.8 billion), the U.K. (USD 3.2 billion) and France (USD 2 billion)» [7].

The Massachusetts Institute of Technology magazine MIT Technology has published a story about ten technologies in 2020 that will radically change the world in the future, namely: 1) mega-constellations of satellites; 2) pocket artificial intelligence; 3) artificial intelligence in microbiology; 4) Quantum computers; 5) climate change forecasting; 6) anti-aging drugs; 7) secure Internet; 8) digital money; 9) hyperpersonalized medicine; 10) differential privacy [8].

Thus, the processes of digitalization of all spheres of the economy, which are focused on the mass consumer and contribute to the development of a safe environment become the key to the successful operation of many organizations of tangible and intangible production.

One of the tools for assessing the innovation potential and knowledge intensity of the economy is a system of international indices: the Global Innovation Index (GII) and the Global Competitiveness Index (GCI). Competitiveness rating data for some countries are presented in Table 2.

This list only confirms the trends of leadership in the world economy and the ability to carry out large-scale projects, for example, in space. 
Table 2

The Global Competitiveness Index for some countries in 2019 [9]

\begin{tabular}{|c|c|c|}
\hline Rank & Economy & Score \\
\hline 1 & Singapore & 84.8 \\
\hline 2 & United States & 83.7 \\
\hline 3 & Hong Kong SAR & 83.1 \\
\hline 4 & Netherlands & 82.4 \\
\hline 5 & Switzerland & 82.3 \\
\hline 6 & Japan & 82.3 \\
\hline 7 & Germany & 81.8 \\
\hline 8 & Sweden & 81.2 \\
\hline 9 & United Kingdom & 81.2 \\
\hline 10 & Denmark & 81.2 \\
\hline 43 & Russian Federation & 66.7 \\
\hline 85 & Ukraine & 57.0 \\
\hline
\end{tabular}

Dynamics of the number of researchers engaged in R\&D in some regions of the world and in Ukraine (per 1 million people) presented in Figure 1 [10]. A comparative analysis of the dynamics of this indicator in different regions shows the real actions of government and business to improve the lives of its population through innovation.

The analysis of the relationship between GCI and the number of R\&D researchers in different countries is presented in table 4 based on data [10].

Table 4

\section{The relationship between GCI and the number of $R \& D$ researchers in different countries}

\begin{tabular}{|c|c|c|}
\hline \multirow[b]{2}{*}{ Country } & \multicolumn{2}{|c|}{ Statistical indicators } \\
\hline & Model & $\begin{array}{c}\text { Coefficient of determination } \\
\left(\mathbf{R}^{2}\right)\end{array}$ \\
\hline United Kingdom & $y=-9,02 x+4171,6$ & $\mathrm{R}^{2}=0,09$ \\
\hline Germany & $y=5764,5 x-0,209$ & $\mathrm{R}^{2}=0,59$ \\
\hline Ukraine & $\mathrm{y}=0,837 \mathrm{x}^{2}-134,69 \mathrm{x}+5653,9$ & $\mathrm{R}^{2}=0,47$ \\
\hline USA & $y=-4,565 x^{2}+73,184 x+3739$ & $\mathrm{R}^{2}=0,39$ \\
\hline Japan & $y=0,777 x^{2}-14,921 x+5298,3$ & $\mathrm{R}^{2}=0,0079$ \\
\hline
\end{tabular}




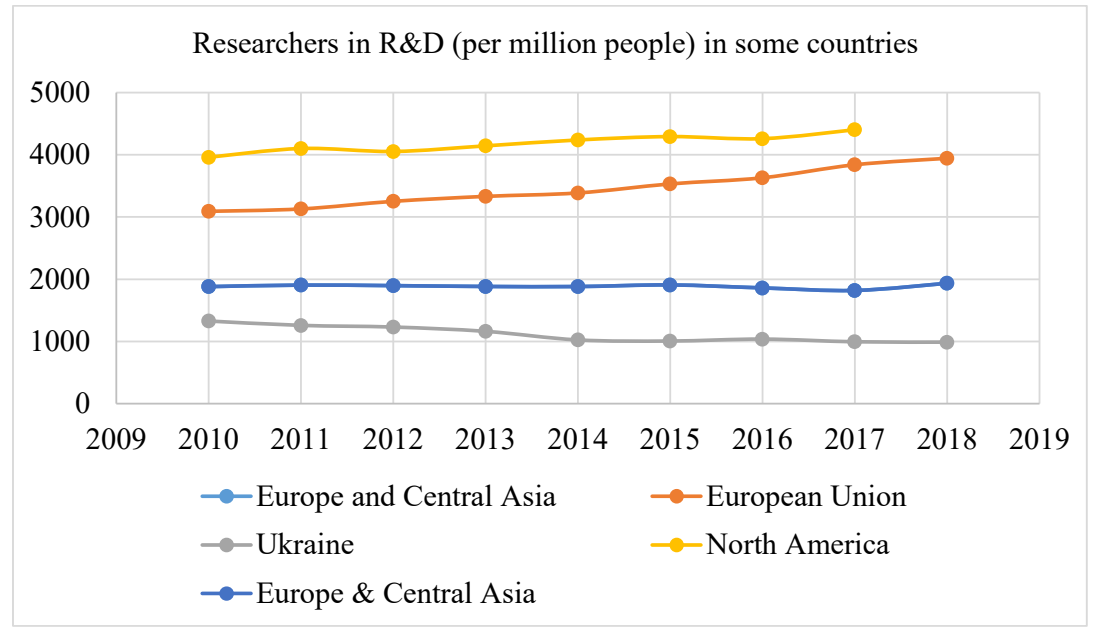

Figure 1. Dynamics of the number of researchers engaged in $R \& D$ in some regions of the world and in Ukraine (per 1 million people)

Analysis of the data in Table 4 shows the influence of the number of R\&D researchers on the GCI index only in Germany and Ukraine. In addition, a study of the relationship between GCI and R\&D expenditure (\% of GDP) did not show a sufficient relationship between these parameters. Thus, we can conclude that not only the quantitative parameters of innovation form competitive societies but also qualitative features (public procurement of new technologies and products, the relationship of universities with industry, level of state and organizational management, the level of technology development, the degree of use of information technology, etc.).

\section{Scientific and technical trends in the space industry}

The space industry operates not only for the needs of one state. Today, as a consumer and producer, it is very closely integrated into the world economic system. That is why trends in world science, research and development go hand in hand with the processes of development of the aerospace sector. In this aspect, the UNESCO World Science Report [11] should be highlighted, highlighting the common dilemmas facing countries, namely: finding a balance between local and international participation in research; basic and applied 
research; generation of new knowledge and production of knowledge that is in demand in the market; between science in the interests of society and science as the driving force of commercial activity. In Ukraine, the influence of global trends has become noticeable, such as geopolitical events (political conflict with Russia and the occupation of part of Ukrainian territories), environmental crises, energy problems, and the availability of an effective development strategy. The EU's Innovation Development Strategy (Europe-20 Strategy) focused on creating smart, sustainable and inclusive growth that fosters knowledge, innovation, education and the digital society. The development programs of scientific and technological countries around the world have also moved in this direction with varying degrees of success. Thus, the key points in building a strategy for the development of Ukraine's space industry should be the tasks formulated in the UNESCO Report and decisions that include: 1) identifying areas and strategies that have the greatest impact on science and technology, ensure long-term development of society; 2) identification of promising markets for goods and markets for their consumption; 3) identification of risks and different scenarios for the development of scientific and technological development of Ukraine; 4) determination of priority areas of research.

The potential benefits of the technologies discussed in the report are enormous, but if business and government leaders are inactive, they will not have time to benefit or respond to the consequences. Business leaders need to constantly update their organizational strategies to keep up with evolving technologies and use them to increase internal productivity. New technologies will allow you to create completely new products and services and leaders should not be afraid to go beyond the old business models.

The issues of astronautics development, planning of its activity, optimal structure, purpose, proposals for cooperation and financing in Ukraine were considered and discussed at forums, conferences, government meetings many times. It is worth noting the journalistic and scientific works of Yu.Alekseev, V. Gorbulin, L. Kuchma, O. Kashanov, O. Fedorov, O. Degtyarev, E. Kuznetsov, N. Mitrakhov, O. Pilipenko, O. ${ }^{\circ}$ Urusky, V. ${ }^{\circ}$ Usov, A. ${ }^{\circ}$ Shevtsov, A. ${ }^{\circ}$ Shekhovtsov, L. Fedulova and many others. The scheme of choosing the optimal organizational and legal form of organization (enterprise) of the space industry in modern Ukraine, taking into account global trends in aerospace business is presented in the author's work [12]. 
According to the Law of Ukraine «On Scientific and ScientificTechnical Activity», article 48 states that the financial support of scientific and scientific-technical activity in Ukraine is carried out at the expense of state and local budgets, institutions, organizations and enterprises, domestic and foreign customers. works, grants, other sources not prohibited by law. "At the same time, the state undertakes to provide budget funding for scientific and scientific-technical activities in the amount of not less than 1.7 percent of the gross domestic product of Ukraine» [13].

The space industry of Ukraine is an important component of the national economy of Ukraine, as it serves as a driver of many innovative changes in other sectors of the economy and contributes to the development of social, political, economic and environmental spheres of society. The enterprises of the branch, their products and services promote the stimulation of structural changes in industry, economic reforms in the implementation of the policy of «new industrialization» in Ukraine, the main principles of which in the modern sense are to increase the competitiveness of the national economy. technologies according to «Industry $4.0 »$. These changes are primarily aimed at the digitalization of production, a high degree of internationalization of resources and economic relations, the rapid pace of creation and commercialization of innovations. In particular, the priority steps towards «new industrialization» and development of «Industry 4.0» are to provide conditions for the creation of modern new and technological modernization of existing production facilities for in-depth processing of Ukrainian raw materials (especially metallurgical products, wood, agricultural raw materials), which will significantly increase cost manufactured products and merchandise exports of Ukraine. Financial support for innovation in Ukraine is shown in Table 5 [12].

The activity of innovation in Ukraine, shown in table 6 [14].

The analysis of tables 5 and 6 shows the insignificant participation of the state budget in the implementation of innovative measures at modern industrial enterprises of Ukraine. For a long time, Ukrainian companies have actually identified and financed their innovative activities themselves. These trends are reflected in the performance indicators of innovations implemented in practice, the competitiveness of Ukrainian producers and the quality of life of the entire population. 
Expenditures on innovations of industrial enterprises

by sources of financing

\begin{tabular}{|l|c|c|c|c|c|c|c|c|}
\hline \multirow{2}{*}{ Indicator } & \multicolumn{2}{|c|}{2010} & \multicolumn{2}{c|}{2015} & \multicolumn{2}{c|}{2018} & \multicolumn{2}{c|}{2019} \\
\cline { 2 - 9 } & $\begin{array}{c}\text { UAH } \\
\text { million }\end{array}$ & $\begin{array}{c}\text { \% of } \\
\text { total } \\
\text { costs }\end{array}$ & $\begin{array}{c}\text { UAH } \\
\text { million }\end{array}$ & $\begin{array}{c}\text { \% of } \\
\text { total } \\
\text { costs }\end{array}$ & $\begin{array}{c}\text { UAH } \\
\text { million }\end{array}$ & $\begin{array}{c}\text { \% of } \\
\text { total } \\
\text { costs }\end{array}$ & $\begin{array}{c}\text { UAH } \\
\text { million }\end{array}$ & $\begin{array}{c}\% \text { of } \\
\text { total } \\
\text { costs }\end{array}$ \\
\hline Total & 8045,5 & 100,0 & 13813,7 & 100,0 & 12180,1 & 100,0 & 14220,9 & 100,0 \\
\hline Due to & & & & & & & & \\
\hline state budget & 87 & 1,1 & 55,1 & 0,4 & 639,1 & 5,2 & 556,5 & 3,9 \\
\hline local budgets & 5,7 & 0,1 & 38,4 & 0,3 & 13,4 & 0,1 & 109,9 & 0,8 \\
\hline own funds & 4775,2 & 59,4 & 13427,0 & 97,2 & 10742,0 & 88,2 & 12474,9 & 87,7 \\
\hline $\begin{array}{l}\text { funds of resident } \\
\text { investors }\end{array}$ & 31,0 & 0,4 & 74,3 & 0,5 & 109,7 & 0,9 & 72,3 & 0,5 \\
\hline $\begin{array}{l}\text { funds of non- } \\
\text { resident investors }\end{array}$ & 2411,4 & 30,0 & 58,6 & 0,4 & 107,0 & 0,9 & 42,5 & 0,3 \\
\hline other sources & 735,2 & 9,0 & 160,3 & 1,2 & 568,9 & 4,7 & 964,8 & 6,8 \\
\hline
\end{tabular}

Table 6

The number of introduced new technological processes and types of innovative products (goods, services) in industry

\begin{tabular}{|l|c|c|c|c|c|}
\hline \multicolumn{1}{|c|}{ Indicator/ years } & $\mathbf{2 0 1 0}$ & $\mathbf{2 0 1 5}$ & $\mathbf{2 0 1 7}$ & $\mathbf{2 0 1 8}$ & $\mathbf{2 0 1 9}$ \\
\hline $\begin{array}{l}\text { Number of introduced new technological } \\
\text { processes, units }\end{array}$ & 2043 & 1217 & 1831 & 2002 & 2318 \\
\hline including & 479 & 458 & 611 & 926 & 857 \\
\hline low-waste, resource-saving & 2408 & 3136 & 2387 & 3843 & 2148 \\
\hline $\begin{array}{l}\text { Number of introduced types of innovative } \\
\text { products (goods, services), units }\end{array}$ & 663 & 966 & 751 & 920 & 760 \\
\hline
\end{tabular}

The sphere of space activity today includes such areas as launch services with access to space, satellite services, monitoring and information support of the space situation, research and science, orbital economics. These areas are in the political-regulatory environment and are affected by cross-cutting macro trends and wider social and economic consequences.

The success of US aerospace companies in 2019 was assessed by Fortune [2] and presented in Table 7. 
Aerospace \& Defense companies in Fortune rating

\begin{tabular}{|c|l|c|c|c|c|}
\hline Rank & $\begin{array}{l}\text { Name of company } \\
\text { (Industry) }\end{array}$ & $\begin{array}{c}\text { Revenues } \\
\text { (\$millions) }\end{array}$ & $\begin{array}{c}\text { Revenue } \\
\text { percent } \\
\text { change }\end{array}$ & Employees & $\begin{array}{c}\text { Earnings } \\
\text { Per Share } \\
\text { (\$) }\end{array}$ \\
\hline 39 & $\begin{array}{l}\text { Raytheon } \\
\text { Technologies }\end{array}$ & 77046 & $15.9 \%$ & 243200 & 6,41 \\
\hline 40 & Boeing & 76559 & $-24,3 \%$ & 161100 & $-1,12$ \\
\hline 57 & Lockheed Martin & 59812 & $11,3 \%$ & 110000 & 21,95 \\
\hline 83 & General Dynamics & 39350 & $8,7 \%$ & 102900 & 11,98 \\
\hline 96 & Northrop Grumman & 33841 & 12,4 & 90000 & 13,22 \\
\hline 108 & Raytheon & 29176 & $7,8 \%$ & 70000 & 11,93 \\
\hline 226 & Howmet Aerospace & 14192 & $1,3 \%$ & 41700 & 1,03 \\
\hline 236 & Textron & 13630 & $-2,4 \%$ & 35000 & 3,5 \\
\hline 250 & $\begin{array}{l}\text { L3Harris } \\
\text { Technologies }\end{array}$ & 12856 & 108 & 50000 & 7,89 \\
\hline 357 & $\begin{array}{l}\text { Huntington Ingallis } \\
\text { Industries }\end{array}$ & 8899 & 8,8 & 42000 & 13,26 \\
\hline 406 & $\begin{array}{l}\text { Spirit AeroSystems } \\
\text { Holdings }\end{array}$ & 7863,1 & $8,9 \%$ & 18200 & 5,06 \\
\hline 513 & TransDigmGroup & 5517,2 & $44,3 \%$ & 18300 & 13,84 \\
\hline
\end{tabular}

Analysis of table 7 shows the instability of performance indicators in the aerospace business. Even successful companies such as Boeing and Textron can be adversely affected by the unstable situation in the world.

The American magazine SpaceNews, which covers business and political news in the space and satellite industries, has identified twenty projected areas for the development of astronautics in 2020, namely: 1) the emergence of suborbital space tourism; 2) several flights to Mars; 3 ) the return of the Russian missile «Angara 5»; 4) the US Federal Communications Commission will put the C-band frequency band up for public auction; 5) selection of winning companies under the US National Security Program on space launches; 6) satellite maintenance and space debris cleaning programs will be improved; 7) OneWeb and SpaceX begin to deploy a large satellite group; 8) The US National Intelligence Agency engages suppliers of commercial images; 9) SpaceX will increase the number of space launches more than twice; 10) in China, the frequency of space launches will remain high; 11) the Canadian company Telesat 
will select a contractor to form the LEO satellite group;12) new types of small launch vehicles are entering the market; 13) observation of the Earth's surface: the integration of data is becoming a trend; 14) space startups find it harder to raise money; 15) the first flights of «Ariane 6» and «Vega C»; 16) reconfiguration of communication satellites comes first; 17) the Artemis project (the return of humans to the moon) is making progress; 18) launch of satellites engaged in electronic reconnaissance from space; 19) commercial test manned launches; 20) commercial alternatives to NASA's satellite tracking and retransmission system appear [15].

NATO Science \& Technology Organization in its report [16] on the prospects for technology development in societies and their defense sectors notes that «the common factors that link these Fourth Industrial Revolution technologies are that they are all in some way shape or form intelligent, interconnected, distributed and digital (I2D2) in nature».

Management of the space industry of Ukraine is entrusted to the State Space Agency of Ukraine, which is responsible for the development and justification of the National Targeted Scientific and Technical Space Programs of Ukraine. The main directions of the National Targeted Scientific and Technical Space Program of Ukraine for 2013-2018 were: 1) implementation of remote sensing of the Earth from space (in 2018 it was financed by $56.23 \%$ ); 2) improvement of space telecommunication and navigation systems (100\% funded in 2018); 3) conducting space activities in the interests of national security and defense; 4) conducting scientific space research (funded by $98.97 \%$ in 2018); 5) deepening of international cooperation (in 2018 it was financed by 18\%). Tasks «Creation of space complexes» and «Ensuring industrial and technological development» at the expense of the state budget in 2018 were not funded [17].

Features of financing of the enterprises of space industry of Ukraine are presented in the table 8 [17].

The data in table 8 show the chronic non-fulfillment of the state's obligations to the enterprises of the industry, and thus the disappearance of opportunities to obtain competitive advantages in time and scale of production from the lack of financial security and current areas. With such a position of the state, it is difficult to form a proactive development strategy.

Among the most important tasks performed in 2019, the Chairman of the State Space Agency of Ukraine singled out the direction «Carrying out 
Financing the tasks of the National Targeted Scientific and Technical Space Program of Ukraine for 2013-2018

\begin{tabular}{|c|c|c|c|c|c|}
\hline \multirow{2}{*}{ Year } & \multicolumn{5}{|c|}{ State budget, UAH million } \\
\cline { 2 - 6 } & \multirow{2}{*}{$\begin{array}{c}\text { Provided by } \\
\text { the program }\end{array}$} & \multirow{2}{*}{$\begin{array}{c}\text { Actually } \\
\text { funded }\end{array}$} & \multirow{2}{*}{$\begin{array}{c}\text { In \% to the } \\
\text { expected }\end{array}$} & \multicolumn{2}{|c|}{ Taxes and fees paid } \\
\cline { 5 - 6 } & & 25,3 & 26 & 743,6 & 621,7 \\
\hline 2013 & 98,7 & 67,9 & 30 & 711,0 & 577,0 \\
\hline 2014 & 228,5 & 30,3 & 9 & 1077,7 & 946,3 \\
\hline 2015 & 333,0 & 176,3 & 79 & 1041,3 & 888,2 \\
\hline 2016 & 223,6 & 80,1 & 35 & 1159,7 & 1029,4 \\
\hline 2017 & 225,2 & 130,4 & - & 1154,3 & 1154,3 \\
\hline 2018 & - & & & & \\
\hline
\end{tabular}

space activities in the interests of national security and defense», which was fully funded in the amount of 78500.0 thousand UAH. Tasks were also performed: remote sensing of the Earth from space; improvement of space telecommunication and navigation systems; conducting space activities in the interests of national security and defense; conducting scientific space research; creation of space complexes; deepening international cooperation. «Tasks were also performed: remote sensing of the Earth from space; improvement of space telecommunication and navigation systems; conducting space activities in the interests of national security and defense; conducting scientific space research; creation of space complexes; deepening international cooperation». "Arrears on payments to the budget as of September 30, 2020 is UAH 197.4 million. Compared to 01.01.2020, the debt to the budget (arrears) has increased four times. Depreciation of fixed assets by enterprises of the industry on 30.09.2020 is $93 \%$. For 9 months of 2020, the average number of full-time employees of all enterprises in the industry was 13,896 people (economically active enterprises - 13,864 people). Compared to the corresponding data last year, it decreased by 1646 people (or $10.6 \%$ )» [17].

Actual indicates significant problems with the implementation of tasks in the industry as well as problems of management of tangible and intangible components of the industry system. There is a decrease in activity in submitting applications for all industrial property in Ukraine. Ukraine has 
an active international position in the global space market, is a member of international organizations that coordinate space activities, including: the UN Committee on Peaceful Uses of Space (COPUOS), the World Space Research Committee (COSPAR), the Inter-Agency Committee on Space Debris (IADS), The World Organization for Satellite Research (CEOS), the International Astronautical Federation (IAF). Bilateral international agreements on cooperation have been signed with space agencies and agencies of the Russian Federation, Kazakhstan, the United States, Brazil, Argentina, India, China, Israel, Turkey, and the European Union. Ukrainian space companies have established partnerships with the world's leading aerospace companies: «Sea Launch», «Boeing», «Lockheed Martin», EADS, «Daza», «FiatAvia», RSC «Energy». Multilateral agreements and cooperation agreements have been concluded with international organizations and telecommunications companies «Panamsat», «Intelsat», «Intersputnik», «Evtalsat», «Inmarsat» «Evmetsat».

During the years of Ukraine's independence, favorable international legal conditions have been provided for enterprises and institutions of the space industry to enter the world market. The participation of Ukrainian enterprises in international commercial space projects is expanding. The most significant of them are «Sea Launch», «Ground Launch», «Dnipro», «Cyclone-4».

The key element of the mechanism of scientific and technological development of countries is science-intensive production and innovation. Only those countries that implement an innovative development strategy receive significant socio-economic success and global economic leadership.

For the sustainable development of society and the space industry, it is important to try to ensure a full production cycle for the production of civil and defense space products. In today's conditions it is very difficult. However, such areas as remote sensing of the Earth from space remain relevant and profitable; improvement of space telecommunication and navigation systems; conducting space activities in the interests of national security and defense; conducting scientific space research; deepening international cooperation; creation of space complexes and ensuring industrial and technological development. Of course, the financial support of the existing potential in these areas requires the pooling of public and private capital in order to optimally allocate resources and results. 
The author's scheme of formation of perspective directions of development of space branch is presented on Figure 2.

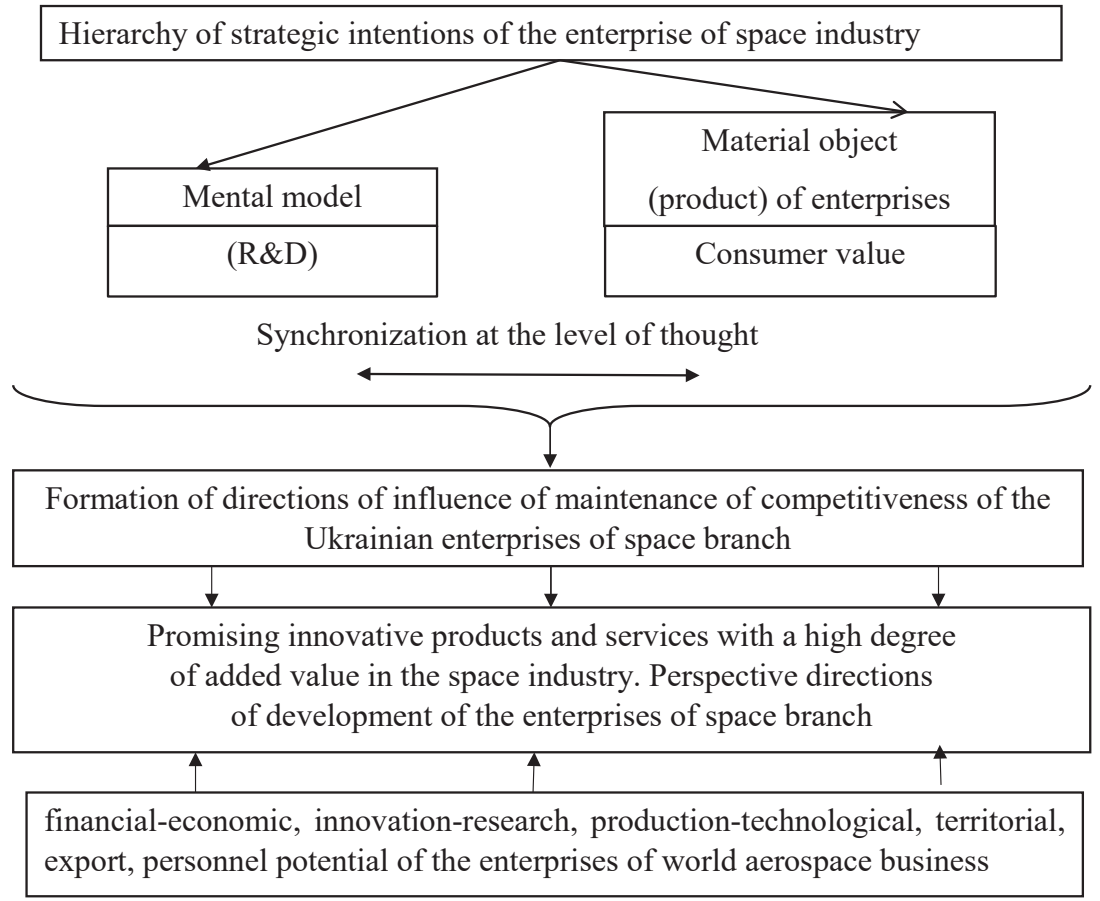

\section{Figure 2. The scheme of formation of perspective directions of development of space industry}

To stimulate and ensure the development of science-intensive production, it is necessary to form an appropriate strategy, which should be formed to ensure the development of science-intensive industries and innovation potential, meet the needs of national economies in research and development in industrial production.

\section{Survey methodology}

Until now, the assessment of promising areas of development of the space industry of Ukraine has been carried out on the basis of the already formed 
scientific and technological potential of enterprises and organizations of the space industry. At the same time, the formation of this potential took place in conditions of sufficient budget funding. Today, the developed countries of the world demonstrate a dynamic policy in the field of innovation, as evidenced by the global dynamics of growth of various types of intellectual property, statistics on the performance of successful companies in the world, especially space companies. The paper conducted a parallel qualitative and quantitative analysis of trends in scientific and technological development of international and national enterprises with an emphasis on enterprises in the space industry.

\section{Findings}

Enterprises of the space industry of Ukraine during the XX-XXI centuries, creating high-tech products and services actually implemented the program «we see what is invisible», showing such qualities as: moving forward on the basis of approval (but not denial); creation of equipment and technology of connection (identification, recognition, management, assessment) of visible and invisible; purification of consciousness (mental development and understanding of responsibility); the opportunity to catch up through the acceleration of innovation processes; beauty (high quality, elegant solution, synchronization, creative mind) as a manifestation of love, wisdom, will; the ability to control oneself in spite of everything. The analysis of the development of scientific and technical support of modern economies with the help of international and national statistics, research data of individual scientists and scientific organizations showed the impact of the potential of economies on further development of innovation processes in space and their application in the national economy. Competitive types of business, degree of their efficiency, problems are analyzed. The degree of influence of the number of researchers on the GCI indicator, which reflects the success of a particular country in the world, was studied. The dynamics of generation and structure of intellectual property objects at the world level and in Ukraine are studied. The degree of implementation of space programs in Ukraine is analyzed, the problems of reorganization of enterprises in the space industry are highlighted. 


\section{Conclusions}

General trend in the $21^{\text {st }}$ century interconnected arenas of science, technology, engineering, and mathematics, changed our world and stimulated industries for diversification of pharmaceuticals, agriculture, and space exploration.

Changes will be permanent, so it is necessary to maintain the flexibility of intellectual property. As activity becomes global, so does intellectual property. As ideology disappears, technology will stimulate development. When economies open to join the world market, competitors cooperate for the common good. Competition is intensifying, favoring innovation. In this situation, a balance of private and public decisions, balancing interests in economic, social, defense, environmental policy is needed.

The analysis of national and international trends in the development of science and technology in the space industry allows us to draw the following conclusions for the formation of a strategy for the development of the space industry in Ukraine: it is worth focusing on research that provides the mass commercial sector; it is necessary to increase financial support for innovation in universities as a basis for reproducing the human resources of knowledge-intensive organizations; a clear mechanism for transforming an innovative idea into an innovative product is needed; the space industry management system needs to be reformed (duplication of functions of the Ministry of Strategic Industries of Ukraine and the State Space Agency of Ukraine); need the corporatization of the industry; requires further investment in tasks related to national security, ecology, production of spacecraft and provision of launch services and communication on a cooperative basis with international counterparties to avoid technological backwardness of scientific, experimental and industrial complex of the industry.

Further research is needed on the optimization and quality of applied and fundamental research in space in Ukraine, taking into account the existing potential and opportunities for international cooperation.

\section{References:}

1. McKinsey: Kakye tekhnolohyy yzmeniat zhyzn, byznes y hlobalnuiu ekonomyku. Available at: https://www.tadviser.ru/index.php (accesed 2 December 2020).

2. Fortune. Available at: https://fortune.com/fortune500 (accesed 8 December 2020). 
3. OECD Science, Technology and Innovation Outlook. Available at: https://www.oecd.org/sti/science-technology-innovation-outlook (accesed 8 December 2020).

4. Joe Lofts (2020) Science trends in 2020: envisioning an interconnected future. Available at: https://www.srgtalent.com/blog/science-trends-in-2020 (accesed 5 December 2020).

5. 8 Trends in Global Science and Technology and What They Mean for Intellectual Property Systems. Available at: https://www.nap.edu/read/2054/chapter/18\#207 (accesed 3 December 2020).

6. Vybir Billa Heitsa: 10 proryvnykh tekhnolohii 2019 roku. Available at: https://24ukr.net/news/vibir-billa-geytsa-10-prorivnih-tehnologiy-2019-roku (accesed 2 December 2020).

7. WIPO. World Intellectual Property Indicators. Available at: https://www.wipo.int/publications/en/series/index.jsp?id=37 (accesed 2 December 2020).

8. MIT Technology Review. Ten technologies of 2020 that will change the future. Available at: https://www.technologyreview.com/digitalmagazine (accesed 1 December 2020).

9. The Global Competitiveness Report 2019. Available at: http://www3.weforum.org/docs/WEF_TheGlobalCompetitivenessReport2019.pdf (accesed 1 December 2020).

10. Oficijnij sajt World Bank. Science \& Technology. Available at: https://data.worldbank.org/indicator (accesed 1 December 2020).

11. UNESCO Science Report: towards 2030 - Executive Summary. Available at: www.unesco.org/termsuse-ccdynd-en (accesed 3 December 2020).

12. Dzhur O.Ie., Mykhailichenko M.A. (2019) Rozvytok orhanizatsiino-pravovykh form pidpryiemstv kosmichnoi haluzi [Development of organizational and legal forms of space industry enterprises]. Infrastruktura rynku [Market infrastructure]. Available at: http://www.market-infr.od.ua/journals/2019/37_2019_ukr/33.pdf (accesed 1 December 2020).

13. Verkhovna Rada Ukrainy. Zakonodavstvo Ukrainy. Zakon Ukrainy «Pro naukovu i naukovo-tekhnichnu diialnist» Available at: https://zakon.rada.gov.ua/ laws/show/848-19\#Text (accesed 4 December 2020).

14. Derzhavna sluzhba statystyky Ukrainy. Statystychnyi shchorichnyk Ukrainy za 2019 rik. Available at: http://www.ukrstat.gov.ua/druk/publicat/kat_u/publ1_u.htm (accesed 4 December 2020).

15. ZIK. Kosmichna haluz: Dvadtsiat prohnoziv na 2020 rik. Available at: https://zik.ua/blogs/kosmichna_haluz_dvadtsiat_prohnoziv_na_2020_rik_963814 (accesed 5 December 2020).

16. Science \& Technology Trends 2020-2040 Exploring the S\&T Edge. Available at: https://2020_TTR_Public_release_final.pdf (accesed 5 December 2020).

17. Derzhavne kosmichne ahentstvo Ukrainy. Zvity pro diialnist. Available at: https://www.nkau.gov.ua/ua/activity/zvity-pro-diialnist (accesed 7 December 2020). 